\title{
探析公路工程建设中的沥青混凝土路面施工及其管理
}

\author{
袁卫星 \\ 新疆天宇建设工程有限责任公司 \\ DOI:10.18686/bd.v2i1.1200
}

[摘 要] 公路工程建设中的励青路面具有表面平整无接缝, 行车振动小, 噪音低, 养护简便,适宜于路面分期修建。并且公路 工程建设中的沥青路面是在柔性基层、半刚性基层上,铺筑一定厚度的沥青混合料作面层的路面结构。为了保障其施工质 量, 本文阐述了公路工程建设中的沥青混凝土路面施工准备, 对公路工程建设中的沥青混凝土路面施工要点及其施工管理 进行了探讨分析。

[关键词] 公路工程建设;沥青混凝土路面;施工准备; 施工要点;施工管理

当前我国公路工程建设中, 大多数都是用沥青混凝土 作为铺路原料, 其中作为原料的沥青混凝土整体质量优劣 直接关系到相关施工道路的性能, 因此要提升道路沥青路 面的质量, 就必须加强沥青混凝土路面施工的质量控制, 从 而保证人们的安全出行。

\section{1 公路工程建设中的沥青混凝土路面施工准备}

公路工程建设中的沥青混凝土路面施工准备主要包 括:(1)熟悉了解设计图纸、招标文件及合同规定,并且对招标 文件及设计图纸进行详细的分析，找出存在的问题及时和 业主进行沟通解决, 并掌握项目规模并准确的计算出沥青 混凝土的数量,为合理确定施工计划打下基础。(2)合理设置 拌和场。拌和场设置需要充分考虑场地位置在运输上的经 济合理性,场地要宽大、平整,并对环境及周围居民无影响, 且不受洪水侵扰。场内运输道路要平整、方便, 进出的各种 机械车辆要方便掉头, 减少相互之间的干扰, 指示标志要齐 全到位。(3)严格施工设备的安装调试。汸青混凝土混合料的 拌和质量及产量, 与所选沥青混凝土拌和设备有重要关系, 拌和设备要能满足工期的要求及工作的连续性要求。路面 的平整度主要取决于摊铺机, 摊铺机应根据路面宽度及路 面等级进行选用, 尽量采用热接缝, 避免冷接缝, 同时推铺机 的生产效率要高。压路机采用双钢轮振动压路机及轮胎压 路机的组合作业, 数量由实际工作量确定。其它设备均要与 整个施工环节相匹配。总之, 设备在选用上要以故障率低且 性能优越为宜。(4)强化人员配置以及材料的准备。沥青混凝 土路面施工时各工序相互联系非常紧密, 而且往往是连续 作业, 所以人员配置都是双班制, 在关键工序上要多配置几 名责任心强、技术较好的人员。材料的质量是沥青混凝土路 面质量好坏的重要因素。材料的数量是否充足直接影响到 工期及路面铺筑的质量, 所以对材料工作要给以充分的重 视和管理, 材料选厂以后要送到具有一定资质的检测机构 或业主指定的检测机构检验合格后方可进场, 同时要随机 抽检,保证进场的材料满足质量技术指标的要求。第一、沥 青是最关键的材料,直接从生产厂家订购,一般设计文件都 有明确要求。第二、各种规格的碎石是沥青混凝土路面的骨
架,是受力的主要支撑材料, 碎石的规格以沥青混凝土各面 层的厚度及配合比确定。工地所用的任何砂石材料最好都 是干燥的, 且所存放场地要硬化, 材料堆放整齐有序, 各种材 料要分开, 避免混料, 且规格型号、产地标识明确。材料有专 人负责, 要覆盖防雨和尘土, 这样可以提高生产率, 并使最终 的沥青混合料质量稳定。(5)科学设计沥青混凝土配合比。沥 青混合料的配合比设计应遵循现行规范的有关规定执行, 通过热拌沥青混和料的目标配合比、生产配合比及生产配 合比验证三个阶段, 确定矿料级配及最佳沥青用量。这项工 作由工地试验室负责完成, 由工地试验室准备原材料, 送到 具有一定资质的检测机构或业主指定的检测机构的专业试 验室去做。

\section{2 公路工程建设中的沥青混凝土路面施工要点分析}

2.1 沥青混凝土拌和施工要点。沥青混凝土拌和时要控 制其温度、油石比及材料的级配。油石比的控制是利用电子 称量器, 对各种材料进行分别称量。而级配的控制方法是两 级控制, 先是从各个冷料仓的出料斗门及皮带转速进行初 控, 经过混合并由运料皮带及提升机送进振动篎, 由振动篮 重新篮分, 振动䇥的尺寸选择要基本与规范中的篮孔尺寸 一致。

2.2 沥青混凝土运输要点分析。沥青混凝土运输时宜用 $15 \mathrm{t}$ 以上的自卸汽车, 由于车辆行驶中的颠䇦, 车厢散热不 均, 与混合料内部形成温差, 会导致混合料产生离析, 因此运 输车要匀速行驶, 避免急刹车。另外, 装好料的汽车要用保温 布覆盖, 然后可以出场。运输时间一般不得大于 $0.5 \mathrm{~h}$, 运输车 到达现场后, 保温布不要急于掀开, 等到推铺时再掀开, 以免 温度损失。

2.3 沥青混凝土的摊铺碾压施工要点。运料车辆到达推 铺机作业面时,推铺机要调好初始状态。推铺厚度、宽度以 设计为准。推铺机慰平板的仰角要准确, 行走速度要稳定, 一 般应控制在 $2 \sim 4 \mathrm{~m} / \mathrm{min}$ 。推铺成型后及时进行碾压, 碾压前 技术人员要认真检查, 发现有局部离析及边缘不规则时要 进行人工修补。轻型双钢轮压路机先稳压一遍,稳压时尤其 注意起步及停车的速度。碾压时力求速度均衡、行走要直、 


\title{
城市景观生态规划的要点分析
}

\author{
高杨 \\ 海南元正建筑设计咨询有限责任公司天津分公司 \\ DOI:10.18686/bd.v2i1.1180
}

[摘要] 随着我国城市化进程的快速发展,环境恶化、特色缺失等一系城市问题也随之暴露出来, 城市景观越来越受到人 们的重视。本文论述了城市景观的特点, 目前城市景观管理中存在的问题,并对如何加强城市景观管理提出了合理化建议。 [关键词] 城市规划; 景观设计; 要点

城市,作为一种物质的表现,是一种可以看到的物质形 态。城市景观生态规划是一定时期内城市发展的目标和计 划,是城市建设的一部分部署。其目的是通过城市与周围影 响地区的整体研究设计,为居民提供良好的工作、居住、游 㮩和交通环境。

\section{1 城市景观生态规划原则}

城市景观生态规划应遵循以下原则：协调人与自然关 系,注重环境容量与可持续发展,考虑对未来变化的灵活性; 保护环境敏感区,对不得已的破坏加以补偿,提高城市景观 的异质性; 在人工环境中努力显现自然,避免物种单调、结
构简单,合理安排、调整空间结构,增加生态多样性; 考虑规 划区外较广阔的空间背景, 较长的历史背景包括生物地理 史、人文历史和自然干扰状况; 居住环境 - 生活质量 - 城 市文化的相互促进,以绿色空间体系为中心的绿化、美化与 净化; 环境管理与生态工程相结合。在景观生态规划设计中 还必须具备 5 个要素: 时空背景、整体景观、景观中的关键 点、规划区域的生态特性和空间属性。

\section{2 城市景观生态规划的程序和主要内容}

2.1 城市景观生态规划的程序

首先收集和调查城市景观生态的基础资料, 再进行景
工作面长度不要大于 $50 \mathrm{~m}$. 稳压完成后即可进行复压, 复压 完毕后用轮胎压路机进行终压, 最后用双钢轮进行感光, 直 到没有轮迹为止。

2.4 合理处理施工缝。沥青路面施工缝处理的好坏对平 整度有一定的影响, 通常连续推铺路段平整度较好, 而接缝 处较差。因此,接缝水平是制约平整度的重要因素之一。处 理好接缝的关键是切除接头, 用 $3 \mathrm{~m}$ 直尺检查端部平整度, 以推铺层面直尺脱离点为界限, 用切割机切缝挖除。新铺接 缝处采用斜向碾压法, 适当结合人工找平, 可消除接缝处的 不平整,使前后两路段平顺衔接。

\section{3 公路工程建设中的沥青混凝土路面工程施工管理分} 析

公路工程建设中沥青混凝土路面工程的施工管理主要 表现为:(1)原材料质量管理。道路施工选用沥青时, 应结合道 路所在地区的气候特点、交通量以及混合料的类型等因素 来确定沥青的标号。沥青混凝土面层的粗集料应洁净、干 燥、无风化、无杂质,应优先选用颗粒形状良好、抗冲击性能 好、石质坚硬的石料。沥青混凝土细集料应洁净、干燥、无风 化、无杂质,可采用天然砂、人工砂及石屑,细集料的棱角有 助于提高材料内摩阻角, 所以细集料也应有适当的颗粒组 成,还需与沥青有良好的粘附性。(2)施工技术的控制管理。 基层和垫层的强度和稳定性对路面的稳定性和路面载荷能 力起着至关重要的作用, 采用结合料稳定的土类应当特别 注意摚拌问题,摚拌不均匀就不能确保基层的强度。对基层 和垫层的施工, 压实工序是重要的环节。针对沥青的施工, 要
准确掌握好搅拌各材料的温度和用量。在施工过程中如果 发现集料表面或底层有泥土等杂物时要进行清除或清洗。 (3)沥青碾压施工管理。沥青混凝土施工碾压通常要经历出 压、复压以及终压等三个过程, 在整个碾压过程中要做好以 下几方面工作:第一、精确控制沥青混合料碾压温度; 第二、 科学控制压路机。作为沥青混凝土路面施工中不可或缺的 设备,压路机的控制主要包含碾压速度与振动频率的控制; 第三、合理控制碾压遍数。在碾压沥青混合料时, 常常会出 现压实不足或过压的现象; 第四、做好碾压后的防护工作。 当天碾压完沥青混凝土层面后, 在其还没有完全冷却之前 不能停放压路机或者其它车辆, 同时还应避免油料、矿料以 及杂物等散落于沥青层面上。

\section{4 结束语}

综上所述,城市化建设的不断推进,使得车流量不断增 大以及重载车辆不断增多, 人们对道路的要求越来越高。因 此必须严格做好沥青混凝土路面各个环节的施工管理,严 格按照施工规范进行施工, 确保沥青路面的工质量。

\section{参考文献:}

[1] 黄耀斌. 市政道路沥青混凝土路面施工技术研究 [J].门窗,2017,(06):87.

[2]薄新定. 市政道路改性沥青混凝土路面施工技术 [J].建材与装饰,2016,(22):261-262.

[3]王祎楠.沥青混凝土路面施工技术及质量控制 [J]. 交通世界,2018,(01):50-51. 